\title{
A study on anxiolytic activity and locomotor behavior of Curcuma amada rhizomes using Wistar albino rats
}

\author{
Prajna V. Raj ${ }^{1}$, Megha Rani N. ${ }^{1 *}$, Roopa P. Nayak ${ }^{1}$, S. N. Rao ${ }^{2}$
}

${ }^{1}$ Department of Pharmacology, Yenepoya Medical College, Mangaluru, Karnataka, India ${ }^{2}$ Department of Pharmacology, Kannur Medical College, Kannur, Kerala, India

Received: 21 May 2018

Accepted: 26 June 2018

*Correspondence to:

Dr. Megha Rani N.,

Email: ranimegz@gmail.com

Copyright: (C) the author(s), publisher and licensee Medip Academy. This is an openaccess article distributed under the terms of the Creative Commons Attribution NonCommercial License, which permits unrestricted noncommercial use, distribution, and reproduction in any medium, provided the original work is properly cited.

\begin{abstract}
Background: Global burden of disease statistics indicate that 4 of 10 most important causes of disease worldwide are psychiatric in origin. Anxiety affects $1 / 8^{\text {th }}$ of total population of the world and is a very important area of research interest in psychopharmacology. Medicinal plants and plant products are the oldest tried health-care products. Their importance is growing not only in developing countries but in many developed countries. Curcuma amada Roxb. (CA) commonly known as Mango Ginger is a rhizomatous aromatic herb which is used in this country for culinary purposes and also to treat various diseases. The rhizomes of Curcuma amada was screened for anxiolytic activity and locomotor behavior in Wistar albino rats.

Methods: Wistar albino rats were divided into three groups as control (Distilled water with $0.1 \% \mathrm{CMC}$ ), standard (Diazepam - $1 \mathrm{mg} / \mathrm{kg}$ ) and test - Ethanolic Extract of Curcuma amada Rhizome (EECAR-250 mg/kg). They were administered drugs orally for a period of 10 days, and screened for anxiolytic activity using Light dark arena model and Actophotometer for assessing the locomotor behavior on the $10^{\text {th }}$ day. The number of crossings and time spent in light arena for anxiolytic activity, and the number of movements in Actophotometer was noted. Data was analyzed by one way ANOVA followed by Tukey Kramer multiple comparison test using GraphPad InStat software.

Results: Curcuma amada $(250 \mathrm{mg} / \mathrm{kg})$ showed increased time spent in light arena and decreased locomotor behavior which was statistically significant.

Conclusions: Curcuma amada possesses significant anxiolytic with CNS depressant activity.
\end{abstract}

Keywords: Actophotometer, Anxiolytic, Curcuma amada, Light dark arena, Locomotor behavior, Wistar albino rats

\section{INTRODUCTION}

Medicinal plants and plant products are the oldest tried health-care products. Their importance is growing not only in developing countries but in many developed countries. Increasing number of patients express a preference for the use of remedies they perceive to be natural.

It is becoming increasingly important for physicians to be familiar with the herbal remedies commonly encountered in their clinical practice. There are number of herbal drugs available for the treatment of various mental disorders but there is a need to explore efficacy of many of them. ${ }^{1}$

Curcuma amada Roxb. (CA) commonly known as Mango Ginger is a rhizomatous aromatic herb which is used in this country for culinary purposes, and also to treat various diseases in Ayurvedic and Unani system of medicine. As the name, Mango ginger (Curcuma amada Roxb.) is a unique spice having morphological resemblance to ginger but imparts raw mango flavor. ${ }^{2}$ Previous studies on the rhizomes of CA have shown that it possesses cytotoxicity and antioxidant, platelet aggregation inhibitory role, anti- 
inflammatory, antimicrobial, analgesic activities and anthelminthic activities. ${ }^{3-8}$

WHO defines health as "A state of complete physical, mental and social well-being and not merely the absence of disease or infirmity". ${ }^{9}$ More than $25 \%$ of people are affected by mental and behavioral disorders at some point during their lives. Anxiety affects one-eighth of total population of the world..$^{10}$ It is a normal emotion under circumstances of threat. There may be circumstances in which the presence of anxiety is maladaptive and constitutes a psychiatric disorder.

Anxiety disorders have core features of fear and worry that cut across the entire spectrum of anxiety disorder subtype, from generalized anxiety to panic disorder, social anxiety disorder and post traumatic stress disorder. The amygdala plays a central role in the fear response and cortico-striatothalamo-cortical circuits are thought to play a key role in mediating the symptom of worry. GABA (Gama amino butyric acid) is a key neurotransmitter in anxiety and the benzodiazepine anxiolytics act upon this neurotransmitter system. Serotonin, norepinephrine and voltage gated calcium channels are also considered as approaches to the treatment of anxiety disorders. ${ }^{11}$ Primary treatments for anxiety-related disorders include the Selective Serotonin Reuptake Inhibitors (SSRI), Serotonin Norepinephrine Reuptake Inhibitors (SNRI), benzodiazepines(BZD), buspirone, and $B$ adrenergic antagonists. ${ }^{12}$ Anxiety is very common among students these days and it has been reported to produce debilitating cognitive effects including difficulties with memory and recalling information especially during examination. ${ }^{13}$ Therefore, it has become a very important area of research interest in psychopharmacology in this decade.

The psychopharmacological activities of Curcuma amada rhizome are seldom studied. The herb grows well in this region and available in abundance. So, it is worthwhile to screen the CA rhizome extract for its anxiolytic activity and effect on locomotor behavior for scientific validation.

\section{METHODS}

This study was conducted in the Experimental lab, Department of Pharmacology at Yenepoya Medical College. The experimental protocol was approved by Institutional Animal Ethics Committee (IAEC).

\section{Plant material}

The rhizome of Curcuma amada grown in Dakshina Kannada district of Karnataka was used. The rhizomes were thoroughly washed, wiped and thinly sliced. The sliced rhizomes were shade dried, coarsely powdered and kept for extraction in Soxhlet apparatus using ethanol as solvent. The solvent was evaporated using Rota vapor and a dark brown aromatic semisolid extract was obtained. This Ethanolic Extract of Curcuma amada rhizome (EECAR) was dissolved with $0.1 \% \mathrm{CMC}$ (carboxy methyl cellulose) and was used as test drug. Based on previous toxicity studies, CA extract dose was fixed to $250 \mathrm{mg} / \mathrm{kg}$. ${ }^{14}$

\section{Drugs}

Test drug - Ethanolic Extract of Curcuma amada $(250 \mathrm{mg} / \mathrm{kg})$ was prepared using Soxhlet apparatus and solvent was evaporated using Rota vapor. Diazepam $(1 \mathrm{mg} / \mathrm{kg})$ was used as standard drug which was obtained from Yenepoya Hospital Pharmacy. ${ }^{15}$

\section{Animals}

Wistar albino Rats weighing 150-300g was used for the study. Animals were kept under standard housing conditions maintained at a room temperature of $24 \pm 1^{\circ} \mathrm{C}$, 12:12 hour light/dark cycle. They had free access to standard pellet diet and water orally. The animals were kept in separate cages, with three animals in each cage. They were marked for the purpose of identification.

Appropriate animals were selected for the study. The animals were grouped as shown in Table 1.

\section{Table 1: Study groups for evaluation of anxiolytic effects and locomotor behavior of EECAR.}

\begin{tabular}{|c|c|c|c|}
\hline Groups & $\begin{array}{l}\text { No of } \\
\text { animals }\end{array}$ & Drugs & Dose, route \\
\hline $\begin{array}{l}\text { I - } \\
\text { Control }\end{array}$ & 6 & $\begin{array}{l}\text { Distilled Water } \\
+0.1 \% \mathrm{CMC}\end{array}$ & $0.3 \mathrm{ml}$, oral \\
\hline $\begin{array}{l}\text { II - } \\
\text { Standard }\end{array}$ & 6 & Diazepam & $1 \mathrm{mg} / \mathrm{kg}$, oral \\
\hline III - Test & 6 & EECAR & $\begin{array}{l}250 \mathrm{mg} / \mathrm{kg} \text {, } \\
\text { oral }\end{array}$ \\
\hline
\end{tabular}

The animals were fed the respective drugs orally for 10 days. On the $10^{\text {th }}$ day, one hour after the oral administration of drugs the experiments were performed to evaluate the anxiolytic activity using Light Dark Arena and the Locomotor behavior using Actophotometer.

The animals were rehabilitated after the study. The animals were acclimatized to the experiment lab for 1 month prior to the conduct of experiment.

\section{Light - Dark Arena ${ }^{16}$}

The original maze is divided into two parts, $1 / 3^{\text {rd }}$ with opaque walls and a cover (dark compartment) whereas the remaining $2 / 3^{\text {rd }}$ is open and illuminated (light compartment). The door between the two compartments permits the animals to move from one compartment to another. The Wistar albino rats were placed in the light compartment and observed for 5 minutes. During this period, the number of entries into the light compartment and the total time spent in light (open) compartment was measured and the observations were tabulated. 


\section{Actophotometer $^{17}$}

An actophotometer has a square arena in which the animal moves. The locomotor activity (horizontal activity) can be easily measured using an actophotometer which operates on photoelectric cells which are connected in circuit with a counter. When the beam of light falling on the photo cell is cut off by the animal, a count is recorded. Each animal was placed in Actophotometer for 5 minutes and the activity score was recorded for all animals and tabulated. Decreased activity score was taken as index of CNS depression.

\section{Statistical analysis}

All the data were represented as Mean \pm SEM (Standard Error of Mean). Comparison between groups were done by one way ANOVA followed by Tukey Kramer multiple comparison test and p value less than 0.05 was considered statistically significant. The statistical analysis was done using GraphPad InStat software.

\section{RESULTS}

\section{Light dark arena}

As seen from the Table 2, following results can be drawn. The diazepam treated group and EECAR group showed increase in the time spent in light area compared to the control group, which was statistically extremely significant.

Table 2: The results of light dark arena.

\begin{tabular}{|lll|}
\hline Groups & Drugs & $\begin{array}{l}\text { Time spent in light } \\
\text { Arena in seconds }\end{array}$ \\
\hline Control & $\begin{array}{l}\text { Normal }(\mathrm{DW})+ \\
0.1 \% \mathrm{CMC}\end{array}$ & $26.66 \pm 3.15$ \\
\hline Standard & Diazepam $(1 \mathrm{mg} / \mathrm{kg})$ & $108.16 \pm 2.72 * * *$ \\
\hline Test & EECAR $(250 \mathrm{mg} / \mathrm{kg})$ & $77.83 \pm 2.12 * * *$ \\
\hline
\end{tabular}

Values are expressed as Mean \pm SEM; (No. of entries and time spent in light arena) $\mathrm{n}=6$; Significance levels when compared with Control: ** $\mathrm{P} \leq 0.01, * * * \mathrm{P} \leq 0.001$

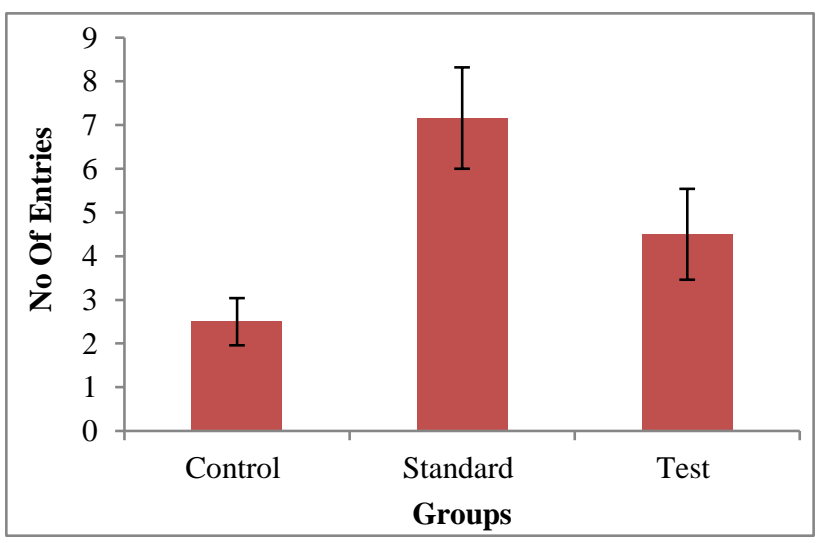

Figure 1: The number of entries made by the animal. Error bar represents the Standard error of mean.
The number of entries into light arena (Figure 1) in the diazepam group was statistically extremely significant and in the EECAR group it was statistically very significant.

As seen from the Table 3, following results can be drawn. The diazepam treated group showed decreased movements in Actophotometer which was statistically extremely significant compared to control group. The EECAR group also showed decreased movements which were statistically very significant compared to control group.

Table 3: The results of Actophotometer.

\begin{tabular}{|lll|}
\hline Groups & Drugs & $\begin{array}{l}\text { No. of } \\
\text { movements }\end{array}$ \\
\hline Control & $\begin{array}{l}\text { Normal }(\mathrm{DW})+ \\
0.1 \% \mathrm{CMC}\end{array}$ & $262.66 \pm 10.01$ \\
\hline Standard & Diazepam $(1 \mathrm{mg} / \mathrm{kg})$ & $122.66 \pm 3.02 * * *$ \\
\hline Test & EECAR $(250 \mathrm{mg} / \mathrm{kg})$ & $214 \pm 8.71 * *$ \\
\hline Values are expressed as Mean \pm SEM; & (No. of cut-offs in the \\
Actophotometer) $\mathrm{n}=6 ;$ Significance levels when compared with \\
Normal Control: $* * \mathrm{P} \leq 0.01, * * * \mathrm{P} \leq 0.001$
\end{tabular}

\section{DISCUSSION}

The present study was performed to evaluate the anxiolytic and locomotor activity of EECAR using Light Dark Arena and Actophotometer respectively. Light dark arena is ethological based approach avoidance conflict test and is sensitive to drugs that effect anxiety. ${ }^{18}$ An anxiolytic agent increases the number of entries and the time spent in light arena. Actophotometer is the instrument used to study the locomotor activity of the animal, which is the index of wakefulness (alertness) of mental activity. ${ }^{19}$ The locomotor activity is reduced by CNS depressant drugs.

Diazepam (BZD), used as standard drug has anxiolytic and CNS depressant property. It acts by enhancing the presynaptic / postsynaptic inhibition through a specific $\mathrm{BZD}$ receptor which is an integral part of $\mathrm{GABA}_{\mathrm{A}}$ receptor $\mathrm{Cl}^{-}$channel complex. ${ }^{20}$ It is well established that BZDs exert their pharmacological effects through positive allosteric modulation of the $\mathrm{GABA}_{\mathrm{A}}$ receptors. Off late, the experiments on $\mathrm{GABA}_{\mathrm{A}}$ receptor subtype-gene knockout mouse lines have greatly facilitated the identification of $\mathrm{GABA}_{\mathrm{A}}$ receptor subtypes that mediate BZDs-induced sedation ( $\alpha 1 \mathrm{GABA}_{\mathrm{A}}$ receptors), anxiolysis ( $\alpha 2$ and $\alpha 3$ $\mathrm{GABA}_{\mathrm{A}}$ receptors), or memory impairment ( $\alpha 5 \mathrm{GABA}_{\mathrm{A}}$ receptors) ${ }^{21}$ Buspirone, selective partial agonists at $5 \mathrm{HT} 1_{\mathrm{A}}$ receptors, mimics the antianxiety properties of BZDs but does not interact with $\mathrm{GABA}_{\mathrm{A}}$ receptors or display the sedative and anticonvulsant properties of BZDs. ${ }^{12}$

In this study, there is an increase in the time spent in the light arena and transitions in the EECAR group when compared with the control group, which is not as much as with the diazepam treated group. This increase may be attributed to its anxiolytic property. In the actophotometer test the decrease in the locomotor activity in the EECAR group compared with the control group can be attributed 
to its CNS depressant activity. The CNS depressant action is not as much as that seen by the diazepam treated group.

So, the possible mechanism of action for the anxiolytic and sedative property of EECAR may be due to agonistic effect on $\alpha 2$ and $\alpha 3$ subtypes of $\mathrm{GABA}_{\mathrm{A}}$ receptors or the partial agonistic effect on $5 \mathrm{HT}_{1}$ receptor.

\section{CONCLUSION}

This study suggests that Ethanolic Extract of Curcuma amada Rhizome has anxiolytic activity that is comparable to diazepam but less sedative than diazepam. Further studies need to be done to elucidate the mechanism of action and active principle responsible for the same.

Funding: No funding sources

Conflict of interest: None declared

Ethical approval: The study was approved by the Institutional Animal Ethics Committee

\section{REFERENCES}

1. Patil PJ, Raghunath PV, Deshmukh TA. CNS Activity of Argyreia Speciosa and Acorus Calamus: A Reveiw. Research and Reveiws: J of Pharmacog Phytochemis. Apr-Jun 2014;2(2):1-9.

2. Varier VPS. Indian Medicinal Plants volume 2: Chennai, Oreint Longman Private Limited; 2007;251.

3. Durairaj P, Malaiyandi K, Shanmugan A, Rajangam U. In vitro antioxidant and cytotoxicity studies of C.amada Roxb.(Mango ginger). Int J Sci Res Publicati. April 2014;4(4): 1-6.

4. Policegoudra RS, Chandrashekhar RH, Aradhya SM, Singh L. Cytotoxicity, Platelet Aggregation Inhibitory and Antioxidant Activity of Curcuma amada Roxb. Extracts. Food technol. Biotechnol. 2011;49(2):162-8.

5. Mujumdar AM, Naik DG, Dandge CN, Puntambekar HM. Antiinflammatory activity of Curcuma amada Roxb. in albino rats. Ind J of Pharmacol. 2000 Nov 1;32(6):375-7.

6. Policegoudra RS, Divakar S, Aradhya SM. Identification of difurocumenonol, a new antimicrobial compound from mango ginger (Curcuma amada Roxb.) rhizome. J of Appli Microbiol. 2007 Jun 1;102(6):1594-602.

7. Mujumdar AM, Naik DG, Misar AV, Puntambekar HM, Dandge CN. CNS depressant and analgesic activity of a fraction isolated from an ethanol extract of Curcuma amada rhizomes. Pharmaceutical biology. 2004 Jan 1;42(7):542-6.

8. Randeep G, Vandna K, Amandeep S. Phytochemical investigation and evaluation of anthelmintic activity of Curcuma amada and Curcuma caesia-A comparative study. J Ethnopharmacol. 2011 Jul 15;2:1-4.

9. Ahuja N. Diagnosis and classification in Psychiatry. In: A Short Textbook of Psychiatry. $7^{\text {th }}$ Ed. New Delhi,
Jaypee Brothers Medical Publishers (P) Ltd; 2011:14.

10. Rout SK, Kar DM, Rout B. Study of CNS activity of leaf extracts of Nerium oleander in experimental animal models. Int J Pharm Sci. 2012;4(4):378-82.

11. Stahl SM. Anxiety disorders and anxiolytics. In: Stahl's essential psychopharmacology. $4^{\text {th }}$ Ed. New York, Cambridge university press; 2013:388-403.

12. O'Donnell JM, Bies RR, Shelton RC. Drug therapy of depression and anxiety disorders. In: L L Brunton, RH Dandan, B C. Knollmann. Goodman and Gilman's The Pharmacological Basis of Therapeutics.13 ${ }^{\text {th }}$ Ed. New York, NY: McGraw-Hill; 2018:267-277.

13. Kumari A, Jain J. Examination Stress and Anxiety: A Study of College Students. Glo J Multidiscipl Studi. 2014 Dec;4(01):31-40.

14. Kumari Bai C, Shanmukananda P. Analgesic Activity of Aqueous Extract of Curcuma Amada (MangoGinger) in Male Albino Wistar Rats. J Evi Bas Med Healthca. 2015;2(40):6662-9.

15. Chandrashekar R, Manohar VR, Rao SN. Acute Anxiolytic Activity of Aqueous extract of Terminalia chebula (AETC) fruit pulp in Rats. Int J Res in Ayur. Pharm. 2013;4(1):112-5.

16. Vogel HG. Psychotropic and neurotropic activity, antianxiety test. In: drug discovery and evaluation: pharmacological assays Vol $1.3^{\text {rd }}$ Ed. New York, Springer Verlag; 2008:622-623.

17. Gangopadhyay A. The central nervous system activity of Barleria prionitis Linn. on the locomotor activity of swiss albino mice using actophotometer. Int $\mathbf{J}$ Pharmaceu and Biolo Archi. 2012; 3(2):403-5.

18. Thippeswamy BS, Mishra B, Veerapur VP, Gupta G. Anxiolytic activity of Nymphaea alba Linn. in mice as experimental models of anxiety. Ind $\mathrm{J}$ Pharmacol. 2011 Feb; 43(1):50-5.

19. Kulkarni SK. Practical Pharmacology and Clinical Pharmacy, $1^{\text {st }}$ Ed. New Delhi, Vallabh Publications; 2009;131-33.

20. Tripathi KD. Drugs used in mental illness: Antidepressant and Antianxiety drugs. Essentials of pharmacology, $7^{\text {th }}$ Ed. New Delhi, Jaypee Brothers Medical Publication (P) Ltd; 2015:454-467.

21. Chen X, Broeyer F, Kam M, Baas J, Cohen A, Gerven J. Pharmacodynamic response profiles of anxiolytic and sedative drugs. Bri J Clin Pharmacol. 2017 May 1;83(5):1028-38.

Cite this article as: Prajna VR, Rani MN, Nayak RP, Rao SN. A study on anxiolytic activity and locomotor behavior of Curcuma amada rhizomes using Wistar albino rats. Int J Basic Clin Pharmacol 2018;7:1557-60. 